DOI: https://doi.org/10.34069/AI/2021.46.10.2

How to Cite:

Zakharov, V.Yu., Volkov, V.A., Ivanova, A.N., Velmozhko, I.N., \& Chirikova, O.B. (2021). The optimality of the option of abolishing serfdom in Russia, implemented in 1861. Amazonia Investiga, 10(46), 20-31. https://doi.org/10.34069/AI/2021.46.10.2

\title{
The optimality of the option of abolishing serfdom in Russia, implemented in 1861
}

\section{Оптимальность варианта отмены крепостного права в России, реализованного в 1861 году}

Received: August 1, $2021 \quad$ Accepted: September 29, 2021

Written by:

Vitaly Yu. Zakharov

https://www.scopus.com/authid/detail.uri?authorId=57222963113

https://elibrary.ru/author_profile.asp?id=325611

https://orcid.org/0000-0002-4308-5943

Vladimir A. Volkov ${ }^{5}$

https://www.scopus.com/authid/detail.uri?authorId=57222960966

https://elibrary.ru/author_profile.asp?id=788168

https://orcid.org/0000-0002-4399-2762

Anna N. Ivanova ${ }^{6}$

https://www.scopus.com/authid/detail.uri?authorId=57222961706

https://elibrary.ru/author_profile.asp?id=1067263

https://orcid.org/0000-0002-5868-5503

Irina N. Velmozhko ${ }^{7}$

https:// elibrary.ru/author_profile.asp?id=287104 https://orcid.org/0000-0002-4509-4069

Olga B. Chirikova ${ }^{8}$

https://elibrary.ru/author_profile.asp?id=1049758 https://orcid.org/0000-0002-0588-3258

\begin{abstract}
The article discusses the controversial issues related to the abolition of serfdom in Russia in 1861: its causes, features of preparation and implementation. The authors focus on the question of whether the implemented version of the abolition of serfdom in Russia was optimal. For this purpose, a comparative analysis of the abolition of serfdom in Russia is carried out with similar reforms in European countries, which could serve as a reference point, primarily in Austria and Prussia. It is concluded that the peasant reform in Russia in 1861 (in the final version) was carried out primarily in the interests of the state and not of individual social groups (landowners and peasants). It is the state that has benefited most from the implementation of this
\end{abstract}

\begin{abstract}
Аннотация
В статье рассматриваются дискуссионные В статье рассматриваются дискуссионные вопросы, связанные с отменой крепостного права в России в 1861 г.: её причины, особенности подготовки и реализации. В центре внимания авторов находится вопрос о том, был ли реализованный вариант отмены крепостного права в России оптимальным? Для этого проводится сравнительный анализ отмены крепостного права в России с аналогичными реформами в европейских странах, которые могли служить в качестве ориентира, прежде всего, в Австрии и Пруссии. В заключение делается вывод о том, что крестьянская реформа в России 1861 г. (в конечном варианте) проводилась, прежде
\end{abstract}

\footnotetext{
${ }^{4}$ Doctor in Historical Sciences, Professor, Moscow State Pedagogical University, Moscow, Russia; Professor, Moscow Aviation Institute (National Research University), Moscow, Russia; Professor, Bauman Moscow State Technical University, Moscow, Russia. ${ }^{5}$ Doctor in Historical Sciences, Professor, Moscow State Pedagogical University, Moscow, Russia; Professor, Ilya Glazunov Russian Academy of Painting, Sculpture and Architecture, Moscow, Russia.

${ }^{6} \mathrm{PhD}$ in Historical Sciences, Associate Professor, Moscow Aviation Institute (National Research University), Moscow, Russia; Associate Professor, Russian Technological University (MIREA), Moscow, Russia.

${ }^{7} \mathrm{PhD}$ in Historical Sciences, Moscow Aviation Institute (National Research University), Moscow, Russia.

${ }^{8}$ Senior Lecturer, Moscow Aviation Institute (National Research University), Moscow, Russia.
} 


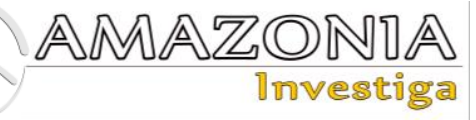

particular version of the reform, both financially and politically. Among the losers there were both peasants (to a greater extent) and landowners (to a lesser extent). The main thing was that the reform provoked the problem of the lack of land of the majority of peasants, which in the future became one of the main reasons for the social explosion and revolutions at the beginning of the XX century.

Keywords: serfdom, abolition of serfdom, peasant reform, Russia, Austria, Prussia.

всего, в интересах государства, а не отдельных социальных групп (помещиков и крестьян). Именно государство больше всех выиграло от проведения именно такого варианта реформы, как в финансовом, так и в политическом отношении. В числе проигравших оказались как крестьяне (в большей степени), так и помещики (в меньшей степени). Главное же заключалось в том, что реформа спровоцировала проблему малоземелья большинства крестьян, что в будущем стало одной из главных причин социального взрыва и революций в начале XX века.

Ключевые слова: крепостное право, отмена крепостного права, крестьянская реформа, Австрия, Пруссия, Россия.

\section{Introduction}

In 2021 we will celebrate the 160th anniversary of one of the most important events in Russian history: liberation of serfs. On February 19, 1861, the long-awaited Manifesto on the abolition of serfdom was issued, which finally ended the shameful phenomenon that caused indignation of the enlightened part of Russian society, but at the same time it was the basis of the socio-economic and political development of the Russian Empire for two centuries. It was a truly significant and epoch-making event in the history of the Russian state.

The peculiarities of the content of the peasant reform of 1861, its orientation had a huge impact on the further development of the country, largely determining the contradictions and problems that Russian society and the state faced at the turn of the XIX-XX centuries and which led to the social explosion and revolutions of 1905-1907 and 1917.

The purpose of this article is to analyze the controversial problems associated with the abolition of serfdom in Russia in 1861. The authors focus on the following questions: why attempts to begin the abolition of serfdom in the first half of the XIX century ended in failure; what are the reasons for the abolition of serfdom in 1861 and which of them was the main one; was there a variant of the abolition of serfdom implemented in 1861 optimal, especially in comparison with the peasant reforms in Austria and Prussia (states that are most similar to the Russian Empire in terms of political and socioeconomic relations); who has benefited most from this option of abolishing serfdom in Russia;

what are the positive and negative consequences of the peasant reform of 1861 .

\section{Theoretical Framework}

In Russian and foreign historiography, a lot of works are devoted to the topic of the abolition of serfdom in Russia. However, many aspects of this topic are still debatable and have not been finally resolved.

The study of issues related to the abolition of serfdom began in the pre-revolutionary period, but was hampered by the lack of access to most archival materials and numerous censorship restrictions. Therefore, no serious analytical studies appeared before 1917. Basically, the case was limited to the publication of memoir literature and collections available at that time, legislative materials from the Complete Collection of Laws of the Russian Empire, Code of Current Laws and materials of the work of editorial commissions. Questions about the reasons for the reform, stages of its development and implementation were practically not covered.

Really serious research on the peasant reform of 1861 began only in the Soviet period, when access to numerous archival funds was opened, and especially intensified by the early 1960s on the eve of the celebration of the centenary of the reform and after that.

On the question of the reasons for the failure of attempts to begin the abolition of serfdom in the first half of the XIX century, in our opinion, the works of N.M. Druzhinin, P.A. Zayonchkovsky, 
M.M. Safonov and S.V. Mironenko should be noted (Druzhinin, 1946; Druzhinin, 1958; Zayonchkovsky, 1968; Safonov, 1988; Mironenko, 1989).

In our opinion, the greatest contribution was made by professors of Moscow State University P.A. Zayonchkovsky, L.G. Zakharova and B.G. Litvak to the development of the central topic about the causes, stages of development and main provisions of the reform of 1861 . In their fundamental monographs, questions about the preparation of the peasant reform were considered in detail, its main stages were highlighted, the main actors and their roles in the development and implementation of the reform were characterized, starting with Emperor Alexander II and his brother Grand Duke Konstantin Nikolaevich and ending with the leaders of the editorial commissions and the main provisions of the reform, the stages of its implementation and the consequences for the further development of the country were analyzed (Zayonchkovsky, 1968; Zakharova, 1984; Zakharova, 2011; Litvak, 1991).

On the issue of the results and consequences of the peasant reform of 1861 , we can note, first of all, the monographs of N.M. Druzhinin "Russian village at the turning point. 1861-1881" (Druzhinin, 1978) and already mentioned B.G. Litvak "Coup of 1861 in Russia: why the reformist alternative was not implemented" (Litvak, 1991). The first of them analyzes the main trends in the development of the Russian village of European provinces in the first two decades after the abolition of serfdom on the basis of the richest factual material. The author's general conclusion turned out to be pessimistic. Despite the proclaimed emancipation of the peasantry, the conditions of the reform led to an increase in the lack of land of the peasants, mass impoverishment, consolidation of backward farming systems and primitive agricultural techniques. B.G. Litvak came to approximately the same conclusions. His monograph contains the most valuable material on the analysis of a lot of statutory documents between peasants and their landowners with specific conditions of liberation. The author comes to the conclusion that the reform as a whole was progressive in nature, but its specific conditions and implementation procedure were unprofitable for peasants (to a greater extent) and landowners. It provoked the emergence of the problem of low land use and low rates of agricultural development in the post-reform period.
In foreign historiography, the peasant reform of 1861 and the circumstances accompanying it have long aroused steady interest. However, generalizing analytical works comparable to the studies of P.A. Zayonchkovsky, L.G. Zakharova and B.G. Litvak have not appeared there. Foreign historians have mainly studied certain aspects of the reform, especially with regard to its impact on the Russian economy and financial system. Among them, we can note the works of D. Bayrau, P. Gotrell and S. Hawk, devoted to the financial and economic nuances of the reform, including peculiarities of conducting repurchase operations (Bayrau, 1997; Gotrell, 1992; Hawk, 1992), as well as monographs of T. Emmons and D. Field the situation of the Russian nobility before and after the reform and its relation with government bureaucracy (Emmons, 1968; Field, 1976; Field, 1992).

However, despite the knowledge of many subjects related to the abolition of serfdom in Russia, a lot of the issues mentioned above, are controversial and unresolved. Their analysis is the subject of this article.

\section{Materials and Methods}

The article is an analytical review of the controversial issues related to the abolition of serfdom in Russia. Therefore, it is prepared on the basis, first of all, of a historiographical analysis and study of published sources, presented mainly in the works of Russian scientists. Among the published materials, it is necessary to highlight the legislative sources presented in the Complete Collection of Laws of the Russian Empire (Kodan, 2006).

The article uses, first of all, logical research methods: analysis, synthesis, comparison, modeling method (construction of a theoretical model of the new social structure of Russia in case of implementation of other possible options for the abolition of serfdom) and private scientific methods of historical research: historical and genetic (when analyzing the reasons for the non-realization of projects for the abolition of serfdom in the first half of the XIX century, as well as the reasons for the preparation and implementation of the reform itself in 18561861), historical and comparative (when comparing the peasant reform in Russia, Austria and Prussia) and historical and typological (when clarifying the question, which variant of the abolition of serfdom can be attributed to the project). The method of structural and functional analysis was also used in the work (for example, when analyzing the content of the reform of 


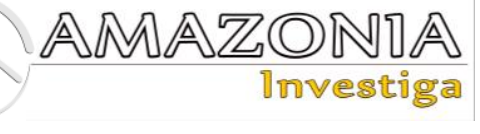

1861, its obvious and hidden goals, interest in the expected results of certain social and political structures and institutions).

\section{Results and Discussion}

Before we talk about the peasant reform of 1861 and its results, in our opinion, we should answer the question why serfdom in Russia lasted longer than in other European countries and was not abolished earlier, at least in the first half of the XIX century? In our article "Discussion aspects of the establishment and development of serfdom in Russia (to the 160th anniversary of the peasant reform of 1861)", published in "Bylye Gody" in № 16(1) 2021 (Zakharov et al., 2021), to which we refer the readers, these issues were analyzed in sufficient detail. In our opinion, the transformation of serfdom relations, which actually spread to all social groups of the population, including the nobility, into the main factor of the socio-economic and political development of the country and their long existence in Russia is explained by the fact that they perfectly fit the mobilization model of the country's development that prevailed under Peter I. With their help, the state was able to concentrate and direct resources, sometimes very scarce, to solve the main task: turning Russia into a powerful military power capable of competing in the international arena with economically stronger European powers.

In the period after Peter, a completely natural process of a kind of "emancipation" of the nobility began, which ended in 1762 with the publication of Manifesto on Freedom to the Nobility and the Charter of the Nobility of 1785 , which led to the destruction of the main logical justification for the need for the existence of serfdom in Russia, which could be expressed in an extremely simple formula: peasants work for the nobles, and they serve the state. After the abolition of compulsory state service for the nobles, serfdom became "meaningless". Therefore, it is quite natural since the end of the XVIII century the process of changing the state policy in relation to serfdom begins. A milestone moment can be considered the Manifesto on the three-day serfdom of 1797 by Paul I, according to which the situation of serfs for the first time did not worsen, but at least slightly, but improved. However, the abolition of serfdom was still far away. During the first half of the XIX century, during the reigns of Alexander I (to a greater extent) and Nicholas I (to a lesser extent), all attempts to begin at the state level the abolition of serfdom, which was perceived by both monarchs as at least a moral evil and a shameful phenomenon, ended in failure. All measures taken by the government ended with the abolition of serfdom in a small part of the country's territory (in Baltic States in 1804-1816) and partial improvements in the situation of certain categories of peasants and in certain areas under Nicholas I (Safonov, 1988; Mironenko, 1989).

What are the reasons for these failures? In our opinion, the first place should be given to the rigid rejection by the majority of the Russian nobility of government measures towards the abolition of serfdom. For the vast majority of nobles, serfdom relations were still beneficial. They were quite satisfied with the unproductive, but free labor of the peasants. And the Russian ruling regime did not dare to go against the opinion of its main social support. In addition, in economic terms, serfdom relations have not yet exhausted themselves. Even by the middle of the XIX century, they provided a small, but still economic growth, although much less than in the competing countries in Western Europe. In the second place, we would put the absence of foreign policy complications for Russia in the first half of the XIX century. The Russian Empire mostly won victories in numerous wars, and foreign policy successes created the illusion of visible prosperity and strengthened the desire of the ruling circles for maximum stability and the preservation of existing orders and relations. Thus, the foreign policy factor acted not in favor, but against measures to abolish serfdom in Russia.

Only the defeat in the Crimean War "opened the eyes" to the true state of things. It showed that Russia has seriously lagged behind the advanced countries of the West in military and economic terms and also revealed all the shortcomings of the management system of Nicholas I. According to the figurative expression of the future Minister of Internal Affairs P. A. Valuev, and at that time the governor of Courland, expressed by him in the note "The Duma of the Russian in the second half of 1855", the brilliant facade of the empire turned out to be completely inconsistent with the real content: "from above there is the shine and from below there is the rot" (Litvak, 1991; Khristoforov, 2016). Many representatives of the so-called "enlightened bureaucracy", of course, saw perfectly well before that the "freezing" of Russia by Nicholas I, the course towards achieving stability in the absence of serious reforms, would sooner or later lead to a lag in the country and a serious crisis. The criticism did not go beyond the literary salons. The defeat in the Crimean War had a stunning effect. Many people 
had a premonition that this would not end well, but no one imagined that it would happen so quickly and cause such a blow to national pride. The main thing was that the Crimean War led to the realization by the highest ruling circles, led by the new Emperor Alexander II, that it was impossible to continue living like this, the country needed serious reforms and, above all, social ones. Otherwise, there was a real threat of falling even further behind the leading European countries and losing the status of a "great power". In our opinion, it was the foreign policy factor (defeat in the Crimean War) that became the main reason for the "great reforms" of Alexander II and, above all, the abolition of serfdom, which from all points of view has long outlived itself. This main reason is layered with accompanying ones. This is an almost 2.5-fold increase in the number of peasant demonstrations in the second half of the 1850s and, especially, the so-called "sober movement" of 1858-1859, which covered most of the provinces of Central Russia, which was an organized action of civil disobedience: refusal to buy alcoholic beverages at increased prices. It was the element of organization in this movement that, apparently, especially frightened the government, much more than a simple quantitative increase in the discontent of the peasants (Zayonchkovsky, 1968). A significant role was also played by the subjective factor, which should include the propensity for reforms of the new emperor Alexander II and, especially, the appearance at the Court of a liberal circle headed by the tsar's younger brother, Grand Duke Konstantin Nikolaevich and Grand Duchess Elena Pavlovna, which united a whole galaxy of future active developers of reforms (for example, brothers N.A. and D.A. Milyutin, Minister of Internal Affairs S.S. Lansky, etc.) (Zakharova, 1984; Zakharova, 2011; Khristoforov, 2016). This circle, headed by such high-ranking figures, constantly pushed the not very decisive Alexander II (in this he was similar to his uncle, Alexander I) to more active actions, did not allow him to fall under the influence of conservatives (at least, until 1860).

The main reform quite logically should have been the peasant reform: abolition of serfdom. It was quite obvious to the already mentioned "enlightened bureaucracy" that serfdom not only discredits the country in European public opinion, but is also the main obstacle to the accelerated development of the economy and overcoming backwardness. In addition, serfdom was a cementing element of the entire socioeconomic system, which was recognized as outdated and did not correspond to the spirit of the times. Therefore, it was necessary to start with him. The difficulty was that the "harmfulness" of serfdom, obvious to the highest bureaucracy, was not at all obvious to the bulk of the nobility, who still remained the main social support of the ruling regime. According to all the annual reports of the Third Department, it turned out that the opinion of the overwhelming part of the nobility about serfdom did not change at all compared to the previous period. $90 \%$ of the nobles were quite satisfied with the unproductive, but free labor of the peasants in the serfdom, and selfish interests clearly prevailed over national interests. Naturally, the government was forced to take into account this position of the majority of the nobility, acting at first in an atmosphere of secrecy, using all sorts of tricks and workarounds.

On the other hand, the development of the peasant reform was simplified by the fact that the Russian reformers were not pioneers, they had before their eyes the experience of the abolition of serfdom in other states with varying degrees of success, which could be used. There were at least three main foreign variants of the abolition of serfdom: French, Austrian and Prussian one. The last two options were generally similar, but not identical. There was also the Russian experience of the abolition of serfdom in the Baltic States in 1804-1819 (so-called "Ostzei" version).

The French option was the least likely for Russia due to the fact that it was a product of the Great French Revolution of 1789-1799, which was completely unacceptable for the absolutist political regime in Russia. The essence of it was the confiscation of most of the noble and monastic lands and their distribution among millions of peasant farms. It was small peasant farms that became the basis of the capitalist development of agriculture in France in the XIX century.

The Austrian and Prussian variants of the abolition of serfdom were more acceptable for Russia. In the Austrian Empire (then the Holy Roman Empire of the German nation), serfdom was formally abolished (where it existed) back in 1781 , on the initiative of the crowned reformer Joseph II. The reform was carried out on the model of the abolition of serfdom in the personal possessions of the imperial family, carried out in 1770. The peasants received personal freedom for free, but all the land remained formally owned by the landowners. However, the peasants were assigned their allotments, and in the sizes that they used before the reform. The peasants became lifelong and hereditary tenants of these allotments with the right of gradual redemption. 


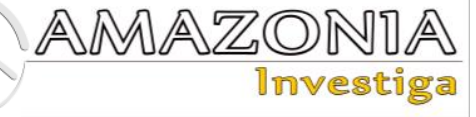

Landlords for several decades had no right to deprive peasants of land. The amount of rent was clearly fixed depending on the quality of the land in special inventory books. In addition, all seigniorial monopolies were abolished, and the right to hunt was sharply restricted. In 1789, all duties were converted into monetary form and amounted to 17 florins 46 1/3 kreutzer from every 100 florins of annual income (i.e. approximately $17.5 \%$ of income). This was all that the peasant had to pay to the owner of the land. However, after the death of Joseph II in 1790, the noble opposition succeeded in slowing down the implementation of this reform, it was difficult to buy out peasant allotments from landlords, the rent began to be set according to the contract, but not higher than $30 \%$ of the crop. In general, the reform has become irreversible. It was finally completed during the revolutionary events of 1848-1849, when the process of redemption of allotments was simplified, and landowners were finally banned from driving peasants off the land, except in cases of late lease payments (Mitrofanov, 2003; Khoros, 1994; Zakharov, 2017).

In Prussia, serfdom was also abolished in two stages: initially, at the initiative of Frederick II in his personal possessions in the 1760s and 1970s, then, on the scale of the whole state in 1807 , according to the reform of G. von Stein - K.-A. von Gardenberg. Moreover, as in the case of Russia, the determining factor was the foreign policy factor: complete defeat in the war with Napoleon in 1806. The reform was carried out almost similarly to the Austrian version. A small difference was the greater participation of the state in the redemption of peasants (at their request) of their allotments by providing a state loan. Just as in Austria, the reform was finally completed only after the revolutionary events of 1848-1849 (Epshtein, 1961). At the same time, in Austria and Prussia, with the formal preservation of the landowners' ownership of land, it was possible to avoid the de-landization of the peasants, which was explained by the fiscal interests of the state.

The Baltic or "Ostzei" version of the abolition of serfdom assumed the personal and landless liberation of the peasants in its purest form. The peasants were deprived of guarantees for the preservation of their allotments. 10 years after the beginning of the reform, landlords received the right to refuse to extend the lease at any time, which meant the right to virtually complete landless peasants, turning them into disenfranchised farmhands.
Summing up, we can say that for the landowners, the most profitable was the Baltic option of completely landless liberation without any restrictions in the exploitation of former serfs. For the peasants, the most profitable option was the French option with the transfer of private property rights to their allotments to them and in pre-reform sizes. But in the conditions of Russia at that time, it was unlikely. Finally, the AustroPrussian version was a compromise, while it assumed the active participation of the state in the process of liberation of the peasants.

We return to the preparation of the peasant reform in Russia. In our opinion, the countdown can be started from the speech of Alexander II to representatives of the Moscow nobility on March 30,1856 , when the emperor declared that rumors that he was going to liberate the peasants had no basis, but sooner or later it should happen, and it would be better if it happened "from above" than to wait for serfdom to be abolished by itself "from below" (Litvak, 1991).

The first stage: from January, 1857 (the creation of another Secret committee on peasant affairs) before the rescript to the Lithuanian GovernorGeneral V.I. Nazimov in November, 1857, when the development of the reform was transferred to the provincial committees and began to be discussed in an atmosphere of publicity, which meant the transition of a kind of "Rubicon" on the part of the government. From that moment, the choice was finally made, and the reform became irreversible. The rescript itself to Nazimov was, in our opinion, a skilful staging on the part of the liberal circle at the Court. Formally, this was a response to the initiative of the Lithuanian nobles (who had clearly acted under pressure from Nazimov) to allow the creation of a provincial committee to develop a reform on the "Ostzey" model. The Lithuanian nobility was expressed the highest favor and was allowed to create such a committee. At the same time, it was recommended to create the same committees in other provinces, which was done under administrative pressure in January-February, 1858. At the same time, the Secret Committee was transformed into the Main Committee. As a result, the Russian nobility was literally forced to start discussing a reform that it did not want. At the same time, the moral right of the nobility to oppose the development of the reform was eliminated. The government could now always declare that the reform was being carried out on the initiative of the nobles themselves, because they wanted it. This was the first and not the last, trick on the part of the liberal-minded higher bureaucracy to neutralize possible protests from 
the nobility, without violating the appearance of decency (Litvak, 1991).

The second stage can be dated from January, 1858 (beginning of the activity of the provincial committees on the peasant question) until February, 1859 (completion of the activities of the provincial committees and creation of editorial commissions). At this stage, the center of gravity in the development of the reform was shifted in the province, apparently on the principle that "it is more visible on the ground". Each provincial committee (consisting of deputies elected by the local nobility, two from each county, as well as two representatives from the government) had to prepare its own project for the liberation of the peasants by the end of the year, based on the peculiarities of the relation between peasants and landowners in this area. The overwhelming majority of the committees put forward the principle of landless emancipation on the "Ostsee" model. This is not surprising, given the maximum profitability for landowners of this particular option of abolishing serfdom, as we have already discussed.

The third stage dates from the period from February, 1859 to February, 1861 and is characterized, first of all, by the activities of editorial commissions headed by a personal friend of Alexander II, Ya.I. Rostovtsev. The commissions consisted of 38 people: 17 were representatives of ministries and departments and 21 were specially invited experts of Rostovtsev's personal choice, naturally with the consent of the emperor (scientists, financiers, public figures, "knowledgeable" landowners). According to the structure, editorial commissions consisted of four departments: economic, headed by N.A. Milyutin, administrative, headed by P.A. Bulgakov, legal headed by S.M. Zhukovsky and financial headed by M.H. Reutern. The main task of the commissions was to bring together all the provincial projects and create on their basis a single Provision on the liberation of the peasants. However, it soon became clear that the regional differences are so great that it is impossible to create a single project. The most important thing was that in the course of the work of the editorial commissions, the very principle of liberation changed radically: instead of landless liberation according to the Baltic version, liberation for ransom with mandatory allotment of land to peasants. The reasons for this change were fears of a possible mass "proletarization of the peasants", which could have an extremely negative impact on the fiscal interests of the treasury, as well as lead to an increase in crime and destabilization of the situation in the country.
The main role was played by the unrest of the peasants in Estonia in the summer and autumn of 1858 ("war in Mahtra"), which discredited the very principle of landless liberation in the eyes of the government. As a result, according to the initial draft of the editorial commissions, developed under the leadership N.A. Milyutin and supported by the liberal majority of the commissions, it was assumed that the peasants would be gradually released with the transfer to lifelong and inherited use, but on the right of communal property, estates and arable plots and in the amounts that were in use by the peasants before the reform. The only exceptions were cases when the landowner had less than $1 / 3$ of arable land left, then the peasants could have had sections of land held in favor of the landlords. The segments were considered as the exception, not the rule. Such an approach took into account the interests of the peasants as much as possible and was supposed to guarantee them from low land. During the redemption operation, the main role was to be played by the state, which paid the landowner the redemption amounts for the peasants at a time, minus the debts of the landowners, then provided a loan to the peasants, who had to pay off the state for about half a century.

However, after the sudden death of Ya.I. Rostovtsev in February, 1860 and the appointment of the conservative Minister of Justice V.N. Panin as chairman of the editorial commissions and then the discussion of the draft editorial commissions in the Main Committee (October, 1860 - January, 1861) and the State Council (January - February, 1861), its content was significantly changed. First, the norms of the highest allotment in the Chernozem and especially Non-Chernozem provinces were significantly reduced (by about $1 / 3$ ). In the nonChernozem zone, the highest shower allotment was from 3 to 7 tithes, the lowest-from 1 to 2.3 tithes (according to the rule, the lowest allotment was $1 / 3$ of the highest allotment). In the chernozem zone, the highest allotment was from 2.7 to 6 dessiatines, and the lowest was from 0.8 to 2 dessiatines. A single "decree" allotment of 6 to 12 tithes was established in the steppe zone. At the same time, landowners provided in the vast majority of cases distorted information about the allotments of their peasants, underestimating their size in every possible way (Zayonchkovsky, 1968). As a result, the land plots in favor of the landowner now in the final version of the reform should have become not an exception, but the rule. Secondly, the amount of the rent was increased by about $15-20 \%$, according to which the amount of the redemption amount was 


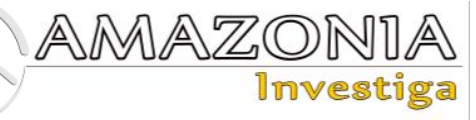

calculated. Thirdly, the rule of gradation of the rent was introduced (except for Ukraine, Lithuania and most of the Belarusian provinces). Its essence was that the rent established for the highest allotment was not reduced proportionally in the case of granting an incomplete allotment to a peasant, but, on the contrary, was calculated inversely proportional to the size of the allotment. In the non-Chernozem provinces, 50\% of the rent was supposed to be paid for the first tithe, $25 \%$ for the second and the remaining $25 \%$ was distributed among the rest of the shower allotment. Thus, the gradation of the dues ensured that the landlords retained their previous income while reducing the size of allotments transferred to the peasants. Fourth, at the suggestion of one of the leaders of the conservative-minded part of the Main Committee and the State Council, Prince P.P. Gagarin, it was added an article on the right of the landowner to provide the peasants with the so-called "gift allotment" in the fourth part of the highest norm for free, while ending all relations with them. The purpose of this innovation was extremely clear: to save as much land as possible from the landowners, which was especially important for the chernozem strip. However, this was not all. The conservative and pro-serf majority of the Main Committee and the State Council initially proposed to conduct a complete revision of the draft editorial commissions and transfer the decision on the issue of land allotments and duties of peasants to the provincial presences for peasant affairs, that is, to transfer the decision on the issue of land allotments and duties of peasants to the provincial to completely transfer this issue to the jurisdiction of the local nobility, which in fact meant a return to the Baltic landless version of the liberation of the peasants. But Alexander II showed, in our opinion, statesmanship and did not go along with the conservatives, supporting the opinion of the minority of the State Council, i.e. the draft of the editorial commissions, although in a distorted form (Zayonchkovsky, 1968; Litvak, 1991).

On February 19, 1861, the Emperor signed the Manifesto on the Abolition of Serfdom and 17 legislative acts devoted to specific measures of this reform (Kodan, 2006). The date of signing was timed to coincide with the sixth anniversary of Alexander II's accession to the throne. The peasants immediately received personal freedom (formally free of charge) and received the status of "free rural inhabitants". At the same time, they received personal civil rights: to freely marry, to transfer property by inheritance, to enter into civil law transactions, to act personally in court as any party to a lawsuit, to transfer to other estates (under certain conditions), to buy a plot of land from a landowner and to use it on the right of communal, farmstead or private property, depending on the region, etc.

At the same time, the reform was carried out not at a time, but in stages. There are three main stages in total. At the first stage (1861-1863), which can be called transitional, the landowner had to agree with his peasants on the conditions of liberation, primarily on the purchase of land. That is, the principle of a voluntary agreement was in effect. If such an agreement could not be reached within two years, the release was carried out "according to the law", i.e. according to local regulations on February 19, 1861. In any case, within two years, statutory documents should have been drawn up, which clearly indicated the number of peasants for this landowner, the number of male workers, the size of allotments for each family, the amount of duties at the time of the reform, etc. The help in drawing up the charters was to be provided by world mediators, elected by the local nobility, approved by the government and acting as its peculiar agents.

At the second stage, which began in 1863, the peasants passed into the category of urgently obliged (or temporarily obliged). This condition is characterized by the fact that the peasants were temporarily obliged to continue performing duties in favor of the landowner, which were regulated until they accumulate $20-25 \%$ of the redemption amount and go to the redemption. Only from this moment on, the peasant received complete freedom from the power of the landowner and was given the opportunity to leave his place of residence (although with restrictions). As we can see, initially the temporary state was not limited by a clear time frame and had to end individually as the peasant accumulated 1/5-1/4 of the redemption amount, depending on the region.

The third stage is the redemption operation or the transition to redemption, which came, as it was already mentioned, when the peasant accumulated $20-25 \%$ of the redemption amount. The remaining $75-80 \%$ was added by the state in the form of a loan at $6 \%$ per annum. The peasant had to pay this loan to the state for 49 years with interest. At the same time, the redemption amount was calculated not from the value of the land, which would be quite logical, but based on the principle of capitalization of the rent of $6 \%$ per annum. That is, it was necessary to find such an amount that, being deposited in the bank, would bring the landowner in the form of $6 \%$ per annum the previous annual rent. For example, 
with an average rent in Russia of 10 rubles a year, the redemption amount was approximately 166 rubles 66 kopecks. To switch to redemption, the peasant had to accumulate about 34 rubles, which was very problematic for a significant part of the peasants with an average annual income of 20-25 rubles per year. In any case, by 1881 , when the temporarily obligated state was legally abolished and everyone was necessarily transferred to redemption, about $1 / 3$ of the peasants still remained temporarily obligated, i.e. they could not accumulate $20-25 \%$ of the redemption amount (Litvak, 1991).

These were, in general terms, the conditions for the liberation of the peasants in 1861 . We try to analyze what consequences they led to. The positive consequences, of course, include the very fact of the abolition of serfdom and the granting of personal freedom and civil rights to serfs. The liberation of the peasants contributed to the formation of a free labor market and accelerated the development of capitalist relations in the economy, especially in industry. The reform of 1861 also brought to life a number of other "great reforms" of Alexander II, in particular the zemstvo and judicial reforms of 1864, which had a positive significance for the further development of the country (for example, thanks to the zemstvo reform, a health care system gradually emerged in rural areas, thanks to which child and female mortality decreased, which led to a rapid population growth by the beginning of the XX century). On the other hand, the very conditions for the liberation of the peasants left much to be desired and caused discontent, both on the part of the peasants and on the part of the landowners. The peasants reacted to the content of the reform rapidly: in the spring and summer of 1861 , according to various data, from 850 to 1300 peasant riots occurred in the country (Zayonchkovsky, 1968; Litvak, 1991). This was a record that lasted until the revolution of 1905-1907. Moreover, the government fully assumed that the reaction of the peasants would be exactly like this. On the eve of the announcement of the Manifesto on the Liberation of the Peasants, a state of emergency was actually introduced in the country, and all garrisons were put on high alert.

What were the peasants dissatisfied with? There were two main reasons: first, a lot of ransom, exorbitant for the vast majority of peasants; second, the right of landowners to make segments of peasant lands in their favor, which amounted to an average of $20 \%$ of the land used by peasants before the reform in Russia, and in some areas much more (for example, in the
Novgorod province it is up to 40\%) (Litvak 1991). The peasants received clearly not enough land because of the segments. The reform actually provoked the emergence of the problem of peasants' lack of land, which was not solved in the post-reform period, and by the beginning of the XX century it had escalated to the limit, becoming one of the main reasons for a whole series of revolutions in Russia. In addition, huge redemption payments, which stretched for almost half a century, led to the fact that most peasants did not have the means to improve the cultivation of the land, hence the extremely low rates of development of agriculture in the post-reform period, unlike industry. Another negative aspect was the preservation of communal land ownership, which the Government did, as it was mentioned above, for fiscal reasons. As a result of periodic land redistribution, communal peasants had no incentive to improve land use, and this was another reason for the low growth rates of agricultural production. Although in fairness, it should be noted that the preservation of the community, apparently, corresponded to the ideas of the majority of peasants about a fair world order. After all, when, according to the reform of P.A. Stolypin in 1906, free exit from the community was allowed, $75-80 \%$ of the peasants remained in the community, despite all the administrative pressure from the government. Another negative, albeit indirect, consequence of the reform of 1861 can be considered the radicalization of public opinion and the emergence of the revolutionary narodnik movement, one of the reasons for the appearance of which was the assessment by a part of society of the peasant reform as predatory towards the liberated peasants.

Not only the peasants were dissatisfied with the reform, but also the majority of landowners. At first glance, this is strange, given that the government seems to have tried to take their interests into account as much as possible. But with a deeper analysis of the content of the reform, the reasons for their discontent become clearer. First, the landowners lost the free labor of the peasants. Secondly, despite all the reservations, more than half of the landowner's land was transferred to the peasants. And, finally, thirdly, during the redemption operation, the state has covered up all the debts of landowners to banks. As a result, about half of the landowners received much less than they expected, and some did not receive anything.

As a result, shouts "We have been robbed!" were heard both from the peasants and from the landowners. But who, then, was the beneficiary 


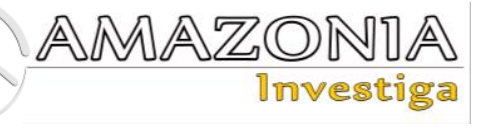

of this reform? The answer, in our opinion, is obvious. The state won the most. It was supposed to receive huge funds from the peasants after the completion of all payments, which, we recall, were supposed to last 49 years, the peasants had to pay about 3 times more than the state spent on this reform. At the same time, the state immediately returned all the debts of the landowners, which were considered almost irrevocable. The fiscal interests of the state were also respected by preserving the community and the principle of mutual responsibility when paying taxes. However, the clear priority of state interests in the implementation of the reform had contradictory consequences. This is the slow pace of agricultural development for the reasons mentioned above, the problem of low land, the preservation of a significant number of remnants of feudal-serf relations in the agricultural sphere, and most importantly, the growth of social contradictions in the countryside, which led to a social explosion at the beginning of the $\mathrm{XX}$ century.

Naturally, the question arises whether it was possible to abolish serfdom according to a more optimal option, which would allow taking into account the interests of both landowners and peasants as much as possible. In our opinion, the Austrian version of the abolition of serfdom would be more preferable. According to it, formally, all the land remained in the ownership of the landowner, but the peasants were assigned to use their allotment land in the amounts that were before the reform with the right of subsequent redemption. Moreover, for several decades, landowners had no right to deprive peasants of the right to use their allotments. We could add more active assistance from the state on lending to peasants for the purchase of their allotment lands. As a result, the problem of land scarcity would be less acute or might not arise at all, and landowners would be satisfied with the preservation of their ownership of land, at least formally. By the way, approximately according to this option, the liberation of peasants in the western provinces of Russia was carried out in 1863. Frightened by the anti-Russian uprising in Poland in 1863, the government created a special commission headed by N.A. Milyutin, who significantly adjusted the conditions of the reform for Belarusian, Ukrainian and Lithuanian peasants. N.A. Milyutin actually implemented the initial program of editorial commissions in this region. Peasant allotments were significantly increased, the segments in favor of landowners were canceled, on the contrary, the rule was the cutting of land to peasant allotments, at least to the pre-reform level (in the Minsk province, the cuts were up to $45 \%$ ) (Litvak, 1991). As a result, social tension has sharply decreased. However, the Russian state did not follow this path in the main part of the territory of the empire, since initially the interests of the treasury, the increase in state revenues, and not the interests of different groups of the population were put at the forefront. As a result, the state won in the short term, but lost in the long term, as the revolutions of 1905-1907 and 1917 showed.

\section{Conclusions}

As a result of the conducted research, the authors came to the conclusion that the abolition of serfdom in Russia in 1861 occurred under the influence of a complex of objective and subjective reasons. The first of them should include, first of all, the foreign policy factor: defeat of Russia in the Crimean War of 18531856, which showed the full extent of the country's backwardness from the advanced countries of the West and led to the realization by the ruling elite led by the new Emperor Alexander II of the need for serious reforms and, above all, the abolition of serfdom under the threat of losing the status of a "great power". A certain role was played by the social factor (growth of peasant demonstrations) and the subjective factor (presence of a "party" of liberal bureaucracy led by the younger brother of the tsar, Konstantin Nikolaevich and the great Princess Elena Pavlovna, who pushed the emperor to more active actions and did not allow to fall under the influence of conservatives for the time being. The analysis of the content of the reform itself allowed us to come to the conclusion that it was carried out, first of all, in the interests of the state, and not the landlords (as it was believed in Soviet historiography) or the peasants, the state that turned out to be the greatest beneficiary from its implementation. The main obstacle to the normal development of the economy and the main destabilizing factor in social and political development were eliminated. At the same time, during the redemption operation, the state had to receive from the peasants almost three times more than it spent on carrying out the reform, and all their debts to the state were deducted from the landlords. The reform itself can hardly be called optimal. Both the majority of peasants and the majority of landowners were dissatisfied. The first is due to huge redemption payments and the loss of part of the cultivated land in the form of segments. The second is due to the loss of free labor of peasants, more than half of the land and the need to repay all debts to the state (if there were any). The consequences of the reform were 
extremely contradictory. On the one hand, the very fact of the abolition of serfdom led to the formation of a free labor market and the final transition to a capitalist economy. On the other hand, too large repurchase payments were the main reason for the extremely slow pace of agricultural development in the post-reform period, since the majority of peasant farms had no money left to improve land use. The preservation of communal land ownership played the role of an additional inhibiting factor, because due to periodic land redistribution, the peasants had no incentive to develop their economy.

A comparison of the reform of 1861 in Russia with the abolition of serfdom in Austria and Prussia allowed us to conclude that the most optimal would be the Austrian option with the preservation of the formal ownership of landowners on all land with the actual granting for several decades of the right to use allotment land to peasants in pre-reform sizes for a fixed rent and with the right of subsequent redemption. Such an option could prevent the emergence of the problem of land shortage and minimize the growth of social discontent, both on the part of landowners and peasants. However, another option was chosen with the priority of state interests, primarily financial ones. Unfortunately, this led to negative consequences and largely provoked a social explosion at the beginning of the XX century, which led to the revolutions of 1905-1907 and 1917 and then the Civil War.

\section{Bibliographic references}

Bayrau, D. (1997). Agrarian structure and peasant protest: on the conditions for the liberation of Russian peasants in 1861. The latest approaches to the study of history in modern foreign historiography. B. $\mathrm{m}$ : National Electronic Library, 3-51. Retrieved at

https://rusneb.ru/catalog/000202_000006_82 1275/

Druzhinin, N.M. (1946). State peasants and the reform of P.D. Kiseleva. Volume 1. Moscow: USSR Academy of Sciences.

Druzhinin, N.M. (1958). State peasants and the reform of P.D. Kiseleva. Volume 2. Moscow: USSR Academy of Sciences.

Druzhinin, N.M. (1978). Russian village at the turn of 1861-1881. Moscow: Science. Retrieved at https://search.rsl.ru/ru/record/01007776602
Emmons, T. (1968). The Russian Landed Gentry and the Peasant Emancipation of 1861. Cambridge: University Press.

Epshtein, A.D. (1961). History of Germany from the Late Middle Ages to the Revolution of 1848. Moscow: Institute of International Relations.

Field, D. (1976). The End of Serfdom. Nobility and Bureaucracy in Russia, 1855-1861. Harvard: University Press.

Field, D. (1992). 1861: "jubilee year". Great reforms in Russia 1856-1874. B. m: National Electronic Library, 73-89. Retrieved at https://rusneb.ru/catalog/000202_000006_87 5551/

Gotrell, P. (1992). The significance of the Great Reforms in the history of the Russian economy. Great reforms in Russia 18561874. B. m: National Electronic Library, 106125. Retrieved at https://rusneb.ru/catalog/000202_000006_87 6072/

Hawk, S. (1992) Banking Crisis, Peasant Reform and Buyout Operation in Russia. 1857-1861. Great reforms in Russia 1856-1874. B. m: National Electronic Library, 90-105. Retrieved at https://rusneb.ru/catalog/000202_000006_87 1334/

Khoros, V.G. (1994). Russian history in comparative coverage. Moscow: Aspect press. Retrieved at https://rusneb.ru/catalog/000202_000006_15 4711/

Khristoforov, I.A. (2016). Great reforms: origins, context, results. Reforms in Russia from ancient times to the end of the 20th century. M.: Editor "Political Encyclopedia", 14-183. Retrieved at https://publications.hse.ru/chapters/1982547 41

Kodan, S.V. (2006). Complete collection of laws of the Russian Empire (to the 175th anniversary of the publication). Russian Legal Journal, 1, 145-149.

Litvak, B.G. (1991). The coup of 1861 in Russia: why the reformist alternative was not realized. Moscow: Politizdat. Retrieved at https://rusneb.ru/catalog/010003_000061_cb fe72b83ba6044db90ee4e2bbcd68a9/

Mironenko, S.V. (1989). Autocracy and Reforms: Political Struggle in Russia at the Beginning of the 19th Century. Moscow: Science». 1989.

Mitrofanov, P.P. (2003). History of Austria from ancient times to 1792. Moscow: State Public Historical Library.

Safonov, M.M. (1988). The problem of reforms in the government policy of Russia at the turn 
of the 18th - 19th centuries. Leningrad: Science.

Zakharov, V. Y., Volkov, V. A., Ivanova, A. N., \& Shkarubo, S. N. (2021). Discussion Aspects of the Establishment and Development of Serfdom in Russia (to the 160th Anniversary of the Peasant Reform of 1861). Bylye Gody, 16(1), 253-261.

Zakharov, V.Yu. (2017). Russian and foreign constitutionalism of the late 18th - 1st quarter of the 19th centuries: the experience of comparative historical analysis. Part 2. Moscow: Prometey. Retrieved at https://avidreaders.ru/book/rossiyskiy-izarubezhnyy-konstitucionalizm-konca-xviii1.html
Zakharova, L.G. (1984). Autocracy and the abolition of serfdom in Russia. 1856-1861. Moscow: Moscow State University.

Zakharova, L.G. (2011). Alexander II and the abolition of serfdom in Russia. Moscow: Rosspen.

Zayonchkovsky, P.A. (1968). Abolition of serfdom in Russia. 3rd edition, revised and enlarged. Moscow: Prosveshcheniye. Retrieved at https://www.hse.ru/data/2012/09/23/124566 3099/Зайончковский\%20П.А.Отмена\% 20крепостного\% 20права\%20в\% 20России.1968..pdf 